\title{
Research on Japanese Cognition of the New Silk Road and the Countermeasures
}

\author{
Yu Wu, Danyu Wu ${ }^{*}$ \\ School of International Studies, Jingdezhen Ceramic Institute, Jingdezhen, 333000, China \\ * Corresponding Author: Danyu Wu
}

Keywords: New Silk Road, Japan, Cognition, Countermeasure

\begin{abstract}
The proposal of New Silk Road of China has attracted worldwide attention and is considered to be "the longest and most potential economic corridor in the world." Japan, the powerful rival of China's East Asian region, views it as a major challenge and has introduced many countermeasures.
\end{abstract}

The proposal of New Silk Road of China has attracted worldwide attention, and dozens of countries along the line have repercussions for their own interests. But as the country only a narrow strip of water with China and the Asian powerful country, Japan's attitude to the proposal is contradictory. The kind of psychology is particularly worth exploring. Its attitude is of great practical significance to China and whether Japan will be able to interact well, cooperate with each other, and designate China's coping strategies in the future.

\section{Japan's Attitude Analysis of New Silk Road of China}

China proposed New Silk Road initiative is to "win-win cooperation and sharing together" as the theme, but in Japan's eyes, this strategy will change the current reorganization of East Asia, the international pattern. The dominant position of the United States for decades will be weakened, and the danger to the national interests of japan.

In view of the present performance in Japan, they think from an economic perspective, new strategic concept of the silk road can not only solve the economy over the past few decades of rapid growth China currently facing overcapacity problems, slow growth, and the establishment of Asian investment bank will make Chinese in international economic influence to expand, let Chinese in the world the enhanced voice, and the early lead in the Asian investment bank, is China exclude Japan, based on a variety of reasons, Japan on whether to join the Asian investment bank attitude is unknown.

In Japan it seems at the political level, past the Silk Road to the West Chinese brought great prosperity in recent years in the Midwest China development is weak, and the new silk road is trying to return to the Western Development Center Chinese, intended to establish a regression type diplomacy, "the sovereign state China reconstruction". In addition, China has also tried to promote Asian investment bank to take the lead in the new regional financial order and take the strategic consideration of the regional strategic decision of the Asian investment and Operation Bureau, and the maritime Silk Road proposed by China in twenty-first Century is an important link to realize the strategy of maritime power.

From the strategic perspective of view, Japan believes that the strategic new silk road is obvious in the capital, Chinese GDP total second in the world, with \$4 trillion of reserves. The investment bank authorized capital of $\$ 100$ billion, as of May 13, 2017. The investment bank has 77 full members, this will be a decisive role in promoting the strategy, if the normal proceed with Silk Road Fund and investment bank under all will move towards the expected development of the China. The Japanese economy scholars pointed out clearly that the twenty-first Century maritime silk road seems to be a modern version of Zheng He's voyages, put forward a new way for the development of cooperation in the Asia Pacific region, can be said to be the extension of the free trade area, you can imagine "The 
Belt and Road 'will become a super huge free trade zone." Moreover, the establishment and development of Asia Investment Bank is bound to compete with the international financial order led by Japan and the United States, which will impact the existing international financial system, which will weaken the influence of the US and Japan in the Asia Pacific region. Japanese conservatism scholars believe that China is not only an advocate of sub investment bank, but also a "controller" of Asian investment bank's related negotiation process. It is even more likely to become the "top decision-maker" in the future Asian investment bank's operation. The rapid development of the Japanese side worry Asian investment bank will expand China in Asia and the world political and economic power, which will be the Japanese led ADB marginalized, Japan also worry that the New Silk Road strategy will weaken the impact of the Japanese overseas market, Japan in the Asia Pacific region and the whole of Japan influence, on the other side of the new silk Chinese the road strategy existing in the financing, political trust, security environment and project investment uncertainty hesitant. There are conflicts between interest and principle manipulation between Asian investment bank and "Silk Road Fund". If these two institutions invest in the same project at the same time, Asian investment bank's loan will become an unconditional loan, which will make Asian investment bank become a subsidiary financial institution of Chinese manufacturers.

And if the Asian investment bank is out of control, each country will likely lose any desire to participate in the Asian investment bank. At the same time, the countries along the line have doubts about excessive reliance on Chinese funds, and the maritime dispute and the political and economic environment along the country will also impede the promotion of the strategy. For example, the demand density of China's high-speed railways is relatively low. If China tries to make the most of the whole line open, it will lead to bad loans and investment. In addition, the construction of China's overseas infrastructure projects is not smooth. China's port construction in Greece, Sri Lanka and investment in Burma will be disrupted.

\section{Japan's Overall Cognition of New Silk Road of China}

Based on all the above doubts and concerns, the idea of "the geo strategy of China Japan's peaceful development and cooperation and win-win cooperation" is difficult to form in the mainstream in Japan. On the contrary, Japanese political circles have been influenced by the geopolitical thought of "sea land confrontation" in the west, and regard China as a strategic rival of Japan in the geopolitical competition of East Asia, and regard the implementation of China's new silk road plan as a major threat to Japan's geopolitical interests. And, with the rapid rise of China's economic power, especially after the first GDP of China surpassed Japan in 2010, Japan's hostility to China is increasing. In recent years, the escalation of territorial disputes between China and Japan has reduced the trust between the two countries to a historical low point. At the same time, when Andouble came to power, it also became increasingly tense and conflict between Sino Japanese relations, and made Sino Japanese relations go against each other from strategic mutual benefit.

Secondly, when Chinese government put forward the New Silk Road strategic plan, Japan is in a dispute over the Diaoyu Islands after Japanese into political, military and diplomatic relations against the background, while the United States has shown a "rebalancing" strategy, the use of Chinese around individual countries to Chinese development concerns, to reinforce the strategic position of the United States is also timely the stimulation of Japan's psychological speculation, to some extent, promote the maintenance of its Chinese's tough stance on the Diaoyu Islands dispute. After the second term of the Obama administration was officially launched, the United States continued to focus the Asia Pacific region as the external focus, and the overall trend of strategic resources to "rebalance" in Asia Pacific has not changed. Until March 2017, when the assistant secretary of state of the United States talked about the Trump administration's Asia Pacific policy, the Asia Pacific rebalancing strategy in the Obama period was over. Although the United States has never expressed intention in the official diplomatic containment but signs have been China, this signal has let Japan completely bared there and then, have confidence, that can make use of the power of the United States China challenge against China, New Silk Road strategy can get American support. 
Finally, from a regional perspective, the rise of China and Japan's two rise in the same time and space, and the trust deficit between the two countries exacerbated the security dilemma between China and Japan, which led to the formation of strategic hedging trend. In particular, Japan's various contradictions, doubts and worries about China's new strategy further activate the spiral of security dilemma between China and Japan, and become the main reason for Japan's resistance to China's New Silk Road strategy. At the beginning of Andouble's post as Prime Minister of Japan, he declared, "Japan is back, and Japan will never become a second country." The case of Japan, in the economic and political dominance has been Chinese gradually reversed, "a honey, B of the arsenic". Japan, the way of thinking of China as an imaginary enemy, has led to Japan's fear of China. This is also directly reflected the Japanese dispute over the Diaoyu Island, the strategic issue of Chinese New Silk Road and the strength of China's confrontation.

\section{Analysis of Japan's Countermeasures}

In view of China's New Silk Road strategy and the construction of the Asian investment bank, Japan has taken a rapid and diversified means to fight against it. Japan is competing fiercely using ODA and China's infrastructure investment. Since 1954, Japan joined the "Cologne Plan" and began to assist in foreign countries. In the past 60 years, Japan has aided 169 countries and 21 regions in many areas, including infrastructure construction, humanitarian relief, health care, culture and education, and economic cooperation. The Andouble Administration tried to take advantage of the trust accumulated in this way and further increase investment from the start stage to curb the implementation of the New Silk Road in China. This is one of the most powerful means to intercepting the interconnection of infrastructure in China.

In addition, Japan is trying to leverage the United States to speed up the " Trans-Pacific Partnership (TPP) negotiations to compete China leading investment bank. As the countries with vested interest of the existing international economic order, Japan and America take the attitude of keeping distance with China's leading sub investment banks. It is generally believed that TPP plays a crucial role in shaping the East Asian economic order. For this reason, the two sides should put down the conflict of interests between the two countries for the time being and transfer the focus to Asia and jointly intercepting the construction of the regional economic order in China. In June 30, 2014, Japan and the United States restarted the TPP negotiations. After that, Japan made concessions to beef imports and American financial and service industries to enter the Japanese market to complete TPP negotiations as soon as possible. In October 20, 2015, the Japanese government released the contents of the TPP negotiations. The tariff rate of all 9081 foreign trade items was $95 \%$. It is the highest degree of liberalization agreement signed by Japan. According to the Japanese media, "the trade barriers between the 12-member countries of TPP have almost been abolished. The huge economic circle thus born will bring opportunities for Japan's national strength and greatly boost the economic development in the Asia Pacific region". The results of the TPP negotiations in Japan and the United States have brought strong impetus to the resistance of Japan to China.

At the same time, Japan's is doing both. On the land, through the run with diplomacy, Japan is ongoing destruction in Chinese behind, making Chinese face in the new energy development and utilization, the field of nuclear power technology, resource processing and management competition with Japan, also increased the area of national strategic concerns China, hinder Chinese "Silk Road Economic Belt" implementation; in the sea, the maritime disputes, will be more stir more muddy water, by constantly draw maritime disputes in Vietnam and Chinese, Philippines, Chinese stimulation of the South China Sea dispute upgrade, positive China teamed up with the existing boundary dispute in India, promoting the relations between Japan and Australia "alliance". The balance of China in India ocean and the Pacific Ocean to the Chinese influence, twenty-first Century "Maritime Silk Road" make trouble.

Japan's cognitive bias and countermeasures of the New Silk Road have interfered with the normal operation of China Silk Road Fund and Asian investment banks, increased the neighboring countries of the New Silk Road initiative intended to create strategic concerns, not conducive to the China New 
Silk Road strategic environment of public opinion, and restricted the normal development of Sino Japanese relations.

At present, the implementation of China's New Silk Road strategy is in its infancy, and the concept of cooperation is still in the process of development. China should seize the opportunity to analyze and classify the neighboring countries by one by one, and take different strategies against them. China should start to stabilize the relations between the neighboring countries and then stabilize the Sino US relations. As Shi Yinhong emphasized, China should not be too loud in many aspects, and cannot talk too highly, too romantic and too general to avoid the gap between words and deeds. We should start from the practice and reduce some of the high key in moderation. We link our practical problems with practical actions to enhance our credibility and make the actions concerning with real important interests not be restrained or restrained by ourselves.

\section{Acknowledgement}

This research is one of the results of the project of Federation of Social Sciences of Jingdezhen City in 2017 named "Feasibility Research on the Opening of New Business Road of Chinese and Japanese Ceramics”.

\section{References}

[1] Liu Jiangyong. The Impact of Geopolitical thoughts on China-U.S.-Japan Relations [J]. Japanese Studies, 2015(3): 1-20.

[2] Liu Guobin, Du Yunhao. On the Ties of Northeast Asian Silk Road: Strategic Thinking of the Construction of Tumenjiang Region (Hunchun) International Cooperation Demonstration Zone [J]. Northeast Asia Forum, 2014(3): 84-92+128.

[3] Xu Chunxiang. Pushing Forward China-Japan-Korea FTA Is the Sole Regional Strategic Choice of China [J]. Northeast Asia Forum, 2014(3): 73-83+128.

[4] Liu Cigui. Some Thoughts on Developing Maritime Cooperative Partnership and Promoting the Building of the 21st Century Maritime Silk Road [J]. International Studies, 2014(4): 1-8+131. 